\title{
The Influence of Work Ethics on Job Performance of Government Employees
}

\author{
Helen R. Benedicto ${ }^{1}$ and Merlita V. Caelian ${ }^{2}$ \\ ${ }^{1}$ Local Government of Cadiz City, Negros Occidental, Philippines \\ ${ }^{2}$ University of Negros Occidental-Recoletos, Bacolod City, Philippines
}

\section{Article history:}

Submitted: 12 February 2021

Revised: 22 March 2021

Accepted: 25 March 2021

\section{Keywords:}

Human resource management

Work ethics

Job performance

Government employees,

Descriptive-correlational

Philippines

\begin{abstract}
Ethics is associated with a positive influence on employee performance. Those who strongly support the practice of work ethics make beneficial changes to the goals and values of the organization. This descriptivecomparative correlational study assessed the influence of work ethics on the level of the job performance of government employees. A researcher-made survey questionnaire administered to 367 employees identified thru proportional random sampling was used. The study revealed that the practice of work ethics is very good; job performance is very satisfactory, which implies that the influence of work ethics on job performance is great. However, significant differences were found when employees were grouped as to their demographic profiles. A significant relationship between work ethics and job performance was discovered; however, most employees' performance is on compliance level only. Hence the need to strengthen ethical values. The findings provided baseline information for an enhanced human resource management program.
\end{abstract}

\subsection{Introduction}

The world is facing challenges and increasing demands for better delivery of public services; hence, the public sector plays a significant role. Gebre-Egziabher (2016) stated that work ethics in the public sector has become crucial. In the Philippines, austerity-driven administrative reformations have changed public administration that influenced employment in the public sector (Mangaoang, 2020). The Philippine Constitution demands that public officials and employees should adhere to the highest standards of ethics. RA 6713 or the Code of Conduct and Ethical Standards for Public Officials and Employees bears eight norms of conduct committed to public interests, professionalism, justness and sincerity, political neutrality, responsiveness to the public, nationalism, and patriotism, commitment to democracy, and simple living.

Studies were reviewed to guide the researcher. These studies focus on the ethical dimension of public administration (Gebre-Egziabher, 2016), on how the quality of work influences job performance (Osibanjo et al., 2018), job performance in the banking sector (Hassan et al., 2013), and effects of pay on employee performance (Aktar et al., 2012; Hameed et al., 2014). Additional studies are on work ethics as a determinant of work performance (Ridzuan et al., 2017), ethical leadership (Aranas, 2016), and local government transparency and effectiveness (Moralista et al., 2015). A related study in Negros Occidental on the implementation of the Anti-Red Tape Act (ARTA) (Alegata \& Caelian, 2019) focused on the satisfaction of students in a state university.

Of the studies reviewed, none focused on work ethics using norms of conduct embodied on RA 6713 as indicators and how these influenced job performance. Thus, the study aimed to assess the practice of work ethics and job performance of government employees using the norms of conduct mandated in RA 6713. Likewise, the relationship between work ethics and job performance was looked into. The findings of the study were used as the basis for an enhanced human resource management program.

\subsection{Framework of the Study}

This paper theorized that work ethics influence job performance. It is primarily anchored on the Theory of Good Governance, which declares that (International Monetary Fund [IMF], 2019) the rule of law, efficiency and accountability of the public sector, and tackling corruption are fundamental components of a framework for economies to thrive. United Nations Development Programme [UNDP] (2008) espouses eight attributes equivalent to the eight norms of conduct of RA 6713. This theory is important as its principles will support the understanding of this study and measure the influence of work ethics on government employees' performance. This is necessary 
to make far-reaching suggestions for enhancing the practice of work ethics and implications for policies on job performance.

The study also anchored on the Virtue Ethics Theory of Aristotle that focused on the character of the individual, which emphasized being good through doing good (Banks, 2012). Further, the theory prioritizes the examination of character and motivations to distinguish right from wrong (Bibus, 2013). In this study, the practice of work ethics of government employees focusing on their character of being good measured thru the eight norms of conduct prescribed in RA 6713. While as to job performance, the use of the Agency Theory is appropriate, which espoused that for any organization to experience and enhance workers' performance, their activities must be well-guided (Osibanjo et al., 2018). Job performance of employees was measured based on the Individual Performance Commitment and Review (IPCR) of the Civil Service Commission (2019)'s Strategic Performance Management System as a guide using the variables of quality, efficiency, and timeliness.

\subsection{Methods}

The study used a descriptive-comparative, correlational research design. A descriptivecomparative research design was employed to describe and compare the practice of work ethics and level of the job performance of government employees and is appropriate because the researcher described a situation in terms of specified variables (Johnson \& Kuby, 2011). The correlational design was used to explain the relationship between work ethics and job performance (Esser \& Vliegenthart, 2017). The respondents of the study were the 367 employees representing employees for CY 2019 as appearing on the plantilla of positions of the LGU identified thru stratified random sampling.

A researcher-made survey instrument based on RA 6713 was utilized to determine the practice of work ethics. Questions on performance were based on the Civil Service Commission (2019)'s Individual Commitment and Review (IPCR). The questionnaire is of three parts. Part I reflects the profile of the respondents. Part II contains Likert-type statements on the practice of work ethics. Part III is also Likert-type statements that measure the level of job performance and a checklist of the challenges encountered by employees in the workplace.

The questionnaire was subjected to content validity using the evaluation criteria by Good and Scates by a jury of five (5) human resource officers from other LGUs. Suggestions and recommendations of the jury were incorporated into the final questionnaire. The validity score was 4.55 , which means that the questions measure what it purports to measure, hence very beneficial, (Louangrath \& Sutanapong, 2018). The questionnaire was subjected to a reliability test using Cronbach's Alpha method to check its internal consistency. It was pilot-tested to 30 selected government employees who did not participate in the study. The Cronbach's Alpha value for the questionnaire on work ethics was 0.934. It indicates that it is reliable (Carmines \& Zeller, 1979), while for job performance was 0.940, excellent, which means that the questions are consistent (Louangrath \& Sutanapong, 2018). This indicates that the variables used are meaningful and suitable for analysis. The practice of work ethics was measured on a scale of 1 to 5 , with five described as excellent, which means that the practice of ethics is almost always; to 1 described as very poor, meaning never practice. The level of job performance is likewise measured on a scale of 1 to 5 with 5 as outstanding, which means extraordinary level to 1 poor, which means below standards.

Descriptive analysis using the mean and standard deviation were utilized to assess the practice of work ethics and the level of performance. Frequency count and percentage were used to measure the challenges encountered by the employees. Normality test using Kolmogorov-Smirnov and Shapiro-Wilk revealed all variables are not normally distributed. Hence, non-parametric statistical tools were used for the comparative and correlational analysis.

\subsection{Results and Discussion}

\section{Practice of work ethics of government employees}

Table $1 \mathrm{~A}$ presents the practice of work ethics of government employees in the areas of commitment to the public interest, professionalism, justness, and sincerity, and political neutrality. As a whole, the practice of work ethics of government employees on these norms of conduct is "very good," which means that they practice these norms oftentimes. Of the four norms of conduct, professionalism was rated the highest interpreted "excellent". In contrast, justness and sincerity were rated the lowest, interpreted as "very good". It was also revealed that younger, female, and employees 
longer in the service were rated "excellent" in professionalism and political neutrality. It was further revealed that male employees were consistently rated the lowest in all the four norms of conduct although still "very good," which means that males practice ethics often only.

The results indicate that government employees complied with their obligations because their practices are within the bounds of the law (RA 6713) as far as professionalism is concerned, aligned with the study of Sable (2014). However, it is noted that government employees tend to take advantage of their positions, succumbed to temptations, and compromise their integrity, as revealed on their lowest rating on justness and sincerity. This implies that governments failed to strengthen standards of ethicality and integrity in the civil service but prioritized the security of tenure of employees over the issues of corrupt practices, which finds support in Gebre-Egziabher (2016). Hence, Sapada et al. (2018) strongly advocate that employees should practice good work ethics.

Table 1A. Practice of Work Ethics of Government Employees

\begin{tabular}{|c|c|c|c|c|c|c|c|c|c|c|c|c|c|c|c|}
\hline \multirow[t]{2}{*}{ Variable } & \multicolumn{3}{|c|}{$\begin{array}{c}\text { Practice of } \\
\text { Work Ethics }\end{array}$} & \multicolumn{3}{|c|}{$\begin{array}{l}\text { Commitment to } \\
\text { Public Interest }\end{array}$} & \multicolumn{3}{|c|}{ Professionalism } & \multicolumn{3}{|c|}{$\begin{array}{l}\text { Justness and } \\
\text { Sincerity }\end{array}$} & \multicolumn{3}{|c|}{$\begin{array}{c}\text { Political } \\
\text { Neutrality }\end{array}$} \\
\hline & $M$ & SD & Int & $M$ & SD & Int & $\mathbf{M}$ & SD & Int & $M$ & SD & Int & $M$ & SD & Int \\
\hline \multicolumn{16}{|l|}{ Age } \\
\hline Young & 4.24 & 0.57 & Ex & 4.19 & 0.63 & VG & 4.31 & 0.66 & Ex & 4.10 & 0.76 & VG & 4.26 & 0.63 & Ex \\
\hline Old & 4.10 & 0.66 & VG & 4.04 & 0.71 & VG & 4.18 & 0.76 & VG & 3.93 & 0.84 & VG & 4.12 & 0.72 & VG \\
\hline \multicolumn{16}{|l|}{ Sex } \\
\hline Male & 4.04 & 0.69 & VG & 4.01 & 0.74 & VG & 4.10 & 0.82 & VG & 3.86 & 0.83 & VG & 4.07 & 0.75 & VG \\
\hline Female & 4.27 & 0.54 & Ex & 4.20 & 0.60 & VG & 4.35 & 0.60 & Ex & 4.13 & 0.76 & VG & 4.28 & 0.61 & Ex \\
\hline \multicolumn{16}{|l|}{ Employment } \\
\hline Regular & 4.42 & 0.53 & Ex & 4.34 & 0.60 & Ex & 4.50 & 0.62 & Ex & 4.39 & 0.66 & Ex & 4.49 & 0.51 & Ex \\
\hline Non-regular & 4.09 & 0.62 & VG & 4.05 & 0.68 & VG & 4.17 & 0.72 & VG & 3.90 & 0.81 & VG & 4.10 & 0.70 & VG \\
\hline \multicolumn{16}{|c|}{ Length of Service } \\
\hline Shorter & 4.11 & 0.65 & VG & 4.08 & 0.70 & VG & 4.18 & 0.74 & VG & 3.94 & 0.83 & VG & 4.13 & 0.72 & VG \\
\hline Longer & 4.31 & 0.51 & Ex & 4.21 & 0.61 & Ex & 4.41 & 0.62 & Ex & 4.20 & 0.71 & VG & 4.34 & 0.56 & Ex \\
\hline As a Whole & 4.17 & 0.62 & VG & 4.12 & 0.67 & VG & 4.25 & 0.71 & EX & 4.02 & 0.80 & VG & 4.19 & 0.68 & VG \\
\hline
\end{tabular}

Table 1B presents the practice of work ethics in the areas of responsiveness to the public, nationalism and patriotism, commitment to democracy, and simple living. Findings revealed that responsiveness to the public was rated the highest interpreted "excellent". Nationalism and patriotism next also interpreted as "excellent", which means that the practice of these norms of conduct is almost always supporting the study of Reyes (2013) and Moralista et al. (2015). The lowest rated norm of conduct is simple living.

When grouped as to demographics, male employees were rated "very good" only in responsiveness to the public and nationalism and patriotism. This means that the males are practicing good work ethics often but not always.

Simple living rated "very good" holds true on all employees regardless of demographics. The finding implies that employees sacrificed their integrity and work ethics for economic reasons in line with the low rating on justness and sincerity. This is supported by the finding that government employees are not receiving a decent living wage as per the survey of IBON Foundation (2021). For Western Visayas, it is Php395.00 per day in CY 2019 as per Wage Order VI-19. However, employees are paid way below because they are non-regular, not entitled to health insurance and retirement privileges. This was revealed in the profile of respondents that $76.3 \%$ are non-regular consistent with the study of Mangaoang (2020). This finding is substantiated by the study of Faragher et al. (2013) that government policies and work practices encouraged the practice of employees engaging in too many loans/debts beyond their capacity to pay. Dulebohn et al. (2009) that for government to demand the true meaning of simple living on government employees, health and safety should be their priority which means that employees contracted loans to finance the health, safety, and education of their family. Further, the salaries of civil servants must reflect the cost of an adequate standard of living to minimize employees' temptation to corruption and to maximize the governments' ability to attract and retain talented employees. 
Table 1B. Practice of Work Ethics of Government Employees

\begin{tabular}{|c|c|c|c|c|c|c|c|c|c|c|c|c|}
\hline \multirow[t]{2}{*}{ Variable } & \multicolumn{3}{|c|}{$\begin{array}{l}\text { Responsiveness } \\
\text { to the Public }\end{array}$} & \multicolumn{3}{|c|}{$\begin{array}{c}\text { Nationalism \& } \\
\text { Patriotism }\end{array}$} & \multicolumn{3}{|c|}{$\begin{array}{c}\text { Commitment to } \\
\text { Democracy }\end{array}$} & \multicolumn{3}{|c|}{ Simple Living } \\
\hline & $M$ & SD & Int & $M$ & SD & Int & $M$ & SD & Int & $M$ & SD & Int \\
\hline \multicolumn{13}{|l|}{ Age } \\
\hline Young & 4.37 & 0.59 & Ex & 4.36 & 0.67 & Ex & 4.16 & 0.70 & VG & 4.07 & 0.66 & VG \\
\hline Old & 4.25 & 0.60 & Ex & 4.24 & 0.74 & Ex & 4.00 & 0.76 & VG & 3.88 & 0.69 & VG \\
\hline \multicolumn{13}{|l|}{ Sex } \\
\hline Male & 4.20 & 0.64 & VG & 4.15 & 0.79 & VG & 3.94 & 0.78 & VG & 3.90 & 0.73 & VG \\
\hline Female & 4.39 & 0.55 & Ex & 4.41 & 0.62 & Ex & 4.19 & 0.69 & VG & 4.04 & 0.64 & VG \\
\hline \multicolumn{13}{|l|}{ Employment } \\
\hline Regular & 4.45 & 0.60 & Ex & 4.50 & 0.68 & Ex & 4.29 & 0.67 & Ex & 4.18 & 0.64 & VG \\
\hline Non-regular & 4.27 & 0.59 & Ex & 4.24 & 0.70 & Ex & 4.02 & 0.74 & VG & 3.91 & 0.68 & VG \\
\hline \multicolumn{13}{|c|}{ Length of Service } \\
\hline Shorter & 4.28 & 0.64 & Ex & 4.25 & 0.75 & Ex & 4.02 & 0.77 & VG & 3.93 & 0.72 & VG \\
\hline Longer & 4.39 & 0.47 & Ex & 4.42 & 0.58 & Ex & 4.21 & 0.65 & Ex & 4.09 & 0.58 & VG \\
\hline As a Whole & 4.31 & 0.60 & Ex & 4.30 & 0.71 & Ex & 4.08 & 0.74 & VG & 3.98 & 0.68 & VG \\
\hline
\end{tabular}

Note: Note: Ex=Excellent: VH-Very High; $\mathrm{H}=$ High

\section{Level of the job performance of government employees}

Table 2 presents that as a whole, the job performance of government employees is "very satisfactory", which means that employees exhibit above-standard job performance. Job performance is measured in terms of quality, efficiency, and timeliness.

Of the three domains of job performance, the quality was rated the highest, interpreted as "very satisfactory". Quality is measured in terms of accuracy of outputs, client satisfaction, creativity and innovativeness, and comprehensiveness of reports. Findings revealed that young, female, regular, and employees who are longer in the service exhibited the outstanding quality of service. Service quality also means that employees are willing to walk the extra mile in striving to perform at a level beyond expectations (Singh, 2016) which were exhibited by employees rendering service during lunch breaks and even beyond office hours. This finding affirmed the studies of Bashir et al. (2012), Usop et al. (2013), and Parvin and Kabir (2011) that employees are capable of improving service quality and work performance. Further, this study found that quality of work coupled with an enabling environment is the highest predictor of job performance. A proof of this is the achievement of the City Environment and Natural Resource Office on their solid waste management project, which was published on Research Gate and presented before the 7th International Conference on Civil, Architecture, Ecology, and Waste Management (CAEWM-17) in 2017 in Manila.

In terms of efficiency, employees who are regular and longer in the service were rated outstanding. In contrast, male employees are consistently rated the lowest on efficiency and timeliness.

The lowest rated indicator of job performance is timeliness, although "very satisfactory" for all employees regardless of demographics. This finding is why the public clamor that government is inefficient, which paves the way for the enactment of the Anti-Red Tape Act (ARTA). The studies of Singh and Singh (2012), Ismyrlis and Moschidis (2015), and Alegata and Caelian (2019) confirmed that although timeliness is "very satisfactory", there is a need of improving services thru the adoption of information technology for accessing frontline services. 
Table 2. Level of job performance of government employees

\begin{tabular}{|c|c|c|c|c|c|c|c|c|c|c|c|c|}
\hline \multirow{2}{*}{ Variable } & \multicolumn{3}{|c|}{ Job Performance } & \multicolumn{3}{|c|}{ Quality } & \multicolumn{3}{|c|}{ Efficiency } & \multicolumn{3}{|c|}{ Timeliness } \\
\hline & $\mathbf{M}$ & SD & Int & $\mathbf{M}$ & SD & Int & $\mathbf{M}$ & SD & Int & $\mathbf{M}$ & SD & Int \\
\hline \multicolumn{13}{|l|}{ Age } \\
\hline Young & 4.15 & 0.73 & vs & 4.26 & 1.06 & OS & 4.17 & 0.70 & vs & 4.13 & 0.68 & vs \\
\hline Old & 3.95 & 0.70 & vs & 4.02 & 0.74 & vs & 3.98 & 0.79 & vs & 3.96 & 0.77 & vs \\
\hline \multicolumn{13}{|l|}{ Sex } \\
\hline Male & 3.94 & 0.75 & vs & 4.03 & 0.79 & vs & 3.93 & 0.83 & VS & 3.91 & 0.80 & VS \\
\hline Female & 4.14 & 0.69 & vs & 4.23 & 1.00 & OS & 4.18 & 0.67 & vs & 4.15 & 0.65 & vs \\
\hline \multicolumn{13}{|l|}{ Employment } \\
\hline Regular & 4.21 & 0.66 & os & 4.32 & 0.66 & OS & 4.23 & 0.76 & os & 4.15 & 0.77 & vs \\
\hline Non-regular & 4.00 & 0.73 & vs & 4.09 & 0.98 & vs & 4.03 & 0.74 & vs & 4.02 & 0.71 & vs \\
\hline \multicolumn{13}{|c|}{ Length of Service } \\
\hline Shorter & 4.00 & 0.76 & vs & 4.09 & 1.03 & vs & 4.02 & 0.77 & vs & 3.99 & 0.74 & vs \\
\hline Longer & 4.17 & 0.58 & vs & 4.26 & 0.61 & OS & 4.22 & 0.70 & os & 4.18 & 0.67 & vs \\
\hline As a Whole & 4.05 & 0.72 & vs & 4.14 & 0.92 & vs & 4.08 & 0.75 & vs & 4.05 & 0.73 & vS \\
\hline
\end{tabular}

Note: VS=Very Satisfactory: OS=Outstanding

\section{Difference in the practice of work ethics}

Tables $3 \mathrm{~A}$ and $3 \mathrm{~B}$ present the differences in the practice of work ethics when employees are grouped as to age, sex, employment status, and length of service.

It was revealed that as a whole, there was a significant difference in the practice of work ethics in terms of age $(p=0.084)$. At the same time, there was no significant difference in terms of sex $(p=0.003)$, employment $(p=0.000)$, and length of service $(p=0.014)$. Hence, the hypothesis is rejected in terms of age but accepted in terms of sex, employment status, and length of service, as shown in the results of the statistical tests conducted. In this case, the effect of demographic characteristics of the respondents on the practice of work ethics is observed on age, but not on sex, employment status, and length of service.

When norms of conduct as dimensions of work ethics were analyzed, there was a significant difference in the area of responsiveness to the public when grouped according to age $(p=0.038)$; sex $(p=0.003)$, and employment status $(p=0.003)$; hence, the null hypothesis is rejected which means that responsiveness to the public differs as practiced by employees. Young, females and regular employees are more responsive, as revealed in their practices of extending adequate service to the public, provides public information, encourages consultation, entertain clients even during lunch breaks and beyond office hours, and always sensitive to the needs of clients as revealed on the results of the survey.

In the area of commitment to the public interest, the results were varied. There was no significant difference in terms of age $(p=0.080)$ and length of service $(p=0.112)$; hence, the null hypothesis is accepted because $p$ values were higher than 0.05 . Young employees who are longer in the service exhibited higher means because they used office resources efficiently, avoids unnecessary spending of public funds, provides a high degree of importance to clients, and upholds public interest over personal interest. Younger employees are more concerned with ethics in the practice of their profession, are more compliant with organizational regulations consistent with the study of Rahiman and Kodikal (2017).

While a significant difference in the commitment to the public interest was revealed between sexes $(p=0.028)$ and employment status $(p=0.000)$, the null hypothesis was rejected because $p$ values are less than 0.05. Female employees and longer in service were rated higher than males and those who are non-regular. Being a regular employee means that there is a commitment to the organization supportive of the study of Sapada et al. (2018).

In the area of professionalism, there was no significant difference in terms of age $(p=0.198)$; hence, the null hypothesis is accepted because the $p$-value is higher than 0.05 , which means that all employees are practicing the tenets of professionalism regardless of whether young or old. But a significant difference was revealed in terms of sex $(p=0.009)$, employment status $(p=0.000)$, 
and length of service $(p=0.005)$; hence the null hypothesis is rejected because $p$-values were less than 0.05 . This means that the practice of professionalism is affected by the demographics of the employees. In this case, employees are selective in the practice of proper behavior at work, degree of excellence, respect for clients, and being peddlers of unjust assistance.

The same situation is true in justness and sincerity, where significant differences were found when employees are grouped as to sex $(p=0.003)$, the status of employment $(p=0.000)$, and length of service $(p=0.000)$; hence, the hypothesis is rejected because $p$ values were lower than 0.05 . It is noted that justness and sincerity revealed the lowest among all the domains of the norms of conduct. This is interpreted that employees succumbed to temptations and can compromise their integrity, as revealed in the results of the survey. However, when employees are grouped according to age, the result is not significant ( $p-0.070)$, which means that young and old employees exhibit the same attitudes toward the public, which is why government service is labeled as inefficient.

In the areas of political neutrality and commitment to democracy, significant differences were found when employees were grouped as to sex, employment status, and length of service. P values were all less than 0.05 ; hence, the null hypothesis was rejected. Both norms of conduct relating to the personal values of the employees toward the administration and government in general.

While nationalism and patriotism were revealed to register significant difference when employees were grouped according to sex $(p=0.002)$ and employment status $(p=0.000)$ because not all employees are observing Filipino values, attend flag ceremony, respect for elders, and use locally produced goods. While in terms of age $(p=0.148)$ and length of service $(p=0.088)$, no significant difference was found, which means that young and old employees, those in government for longer or shorter periods, are practicing the values of a good Filipino citizen.

Table 3A. Difference in the Extent of Practice of Work Ethics of Local Government Employees

\begin{tabular}{|c|c|c|c|c|c|c|c|c|}
\hline \multirow{2}{*}{ Variable } & \multicolumn{4}{|c|}{ Age } & \multicolumn{4}{|c|}{ Sex } \\
\hline & Young & Old & $\mathbf{U}$ & $\mathbf{p}$ & Male & Female & $\mathbf{U}$ & $\mathbf{p}$ \\
\hline \multirow{2}{*}{$\begin{array}{l}\text { Practice of } \\
\text { Work Ethics }\end{array}$} & 4.24 & 4.10 & 15076.0 & 0.084 & 4.04 & 4.27 & 13431.5 & 0.003 \\
\hline & $(0.57)$ & $(0.66)$ & & & $(0.69)$ & $(0.54)$ & & \\
\hline \multirow{2}{*}{$\begin{array}{l}\text { Commitment to } \\
\text { Public Interest }\end{array}$} & 4.19 & 4.04 & 15059.0 & 0.080 & 4.01 & 4.20 & 14237.5 & 0.028 \\
\hline & $(0.63)$ & $(0.71)$ & & & $(0.74)$ & $(0.60)$ & & \\
\hline \multirow{2}{*}{ Professionalism } & 4.31 & 4.18 & 15531.5 & 0.198 & 4.10 & 4.35 & 13817.0 & 0.009 \\
\hline & $(0.66)$ & $(0.76)$ & & & $(0.82)$ & $(0.60)$ & & \\
\hline \multirow{2}{*}{$\begin{array}{l}\text { Justness and } \\
\text { Sincerity }\end{array}$} & 4.10 & 3.93 & 15003.0 & 0.070 & 3.86 & 4.13 & 13415.0 & 0.003 \\
\hline & $(0.76)$ & $(0.84)$ & & & $(0.83)$ & $(0.76)$ & & \\
\hline \multirow{2}{*}{ Political Neutrality } & 4.26 & 4.12 & 15152.5 & 0.097 & 4.07 & 4.28 & 13902.5 & 0.011 \\
\hline & $(0.63)$ & $(0.72)$ & & & $(0.75)$ & $(0.61)$ & & \\
\hline \multirow{2}{*}{$\begin{array}{l}\text { Responsiveness } \\
\text { to the Public }\end{array}$} & 4.37 & 4.25 & 14737.0 & 0.038 & 4.20 & 4.39 & 13457.0 & 0.003 \\
\hline & $(0.59)$ & $(0.60)$ & & & $(0.64)$ & $(0.55)$ & & \\
\hline \multirow{2}{*}{$\begin{array}{l}\text { Nationalism } \\
\text { and Patriotism }\end{array}$} & 4.36 & 4.24 & 15380.0 & 0.148 & 4.15 & 4.41 & 13404.0 & 0.002 \\
\hline & $(0.67)$ & $(0.74)$ & & & $(0.79)$ & $(0.62)$ & & \\
\hline \multirow{2}{*}{$\begin{array}{l}\text { Commitment to } \\
\text { Democracy }\end{array}$} & 4.16 & 4.00 & 14781.5 & 0.043 & 3.94 & 4.19 & 13410.0 & 0.003 \\
\hline & $(0.70)$ & $(0.76)$ & & & $(0.78)$ & $(0.69)$ & & \\
\hline \multirow{2}{*}{ Simple LTiving } & 4.07 & 3.88 & 14117.5 & 0.007 & 3.90 & 4.04 & 14888.0 & 0.123 \\
\hline & $(0.66)$ & (0.69) & & & $(0.73)$ & $(0.64)$ & & \\
\hline
\end{tabular}

Note: the difference is significant when $\mathrm{p} \leq 0.05$ 
Philippine Social Science Journal

Table 3B. Difference in the Extent of Practice of Work Ethics of Local Government Employees

\begin{tabular}{|c|c|c|c|c|c|c|c|c|}
\hline \multirow[b]{2}{*}{ Variable } & \multicolumn{4}{|c|}{ Employment } & \multicolumn{4}{|c|}{ Length of Service } \\
\hline & Regular & $\begin{array}{c}\text { Non- } \\
\text { regular }\end{array}$ & $\mathbf{U}$ & $\mathbf{p}$ & Shorter & Longer & $\mathbf{U}$ & $\mathbf{p}$ \\
\hline \multirow{2}{*}{$\begin{array}{l}\text { Practice of } \\
\text { Work Ethics }\end{array}$} & 4.42 & 4.09 & 8000.0 & 0.000 & 4.11 & 4.31 & 11902.5 & 0.014 \\
\hline & $(0.53)$ & $(0.62)$ & & & $(0.65)$ & $(0.51)$ & & \\
\hline \multirow{2}{*}{$\begin{array}{l}\text { Commitment to } \\
\text { Public Interest }\end{array}$} & 4.34 & 4.05 & 8911.0 & 0.000 & 4.08 & 4.21 & 12732.0 & 0.112 \\
\hline & $(0.60)$ & $(0.68)$ & & & $(0.70)$ & $(0.61)$ & & \\
\hline \multirow{2}{*}{ Professionalism } & 4.50 & 4.17 & 8455.5 & 0.000 & 4.18 & 4.41 & 11594.5 & 0.005 \\
\hline & $(0.62)$ & $(0.72)$ & & & $(0.74)$ & $(0.62)$ & & \\
\hline \multirow{2}{*}{$\begin{array}{l}\text { Justness and } \\
\text { Sincerity }\end{array}$} & 4.39 & 3.90 & 7769.0 & 0.000 & 3.94 & 4.20 & 11653.0 & 0.006 \\
\hline & $(0.66)$ & $(0.81)$ & & & $(0.83)$ & $(0.71)$ & & \\
\hline \multirow{2}{*}{ Political Neutrality } & 4.49 & 4.10 & 8051.5 & 0.000 & 4.13 & 4.34 & 11967.5 & 0.016 \\
\hline & $(0.51)$ & $(0.70)$ & & & $(0.72)$ & $(0.56)$ & & \\
\hline \multirow{2}{*}{$\begin{array}{l}\text { Responsiveness } \\
\text { to the Public }\end{array}$} & 4.45 & 4.27 & 9617.5 & 0.003 & 4.28 & 4.39 & 13318.0 & 0.336 \\
\hline & $(0.60)$ & $(0.59)$ & & & $(0.64)$ & $(0.47)$ & & \\
\hline \multirow{2}{*}{$\begin{array}{l}\text { Nationalism } \\
\text { and Patriotism }\end{array}$} & 4.50 & 4.24 & 9157.0 & 0.000 & 4.25 & 4.42 & 12637.0 & 0.088 \\
\hline & $(0.68)$ & $(0.70)$ & & & $(0.75)$ & $(0.58)$ & & \\
\hline \multirow{2}{*}{$\begin{array}{l}\text { Commitment to } \\
\text { Democracy }\end{array}$} & 4.29 & 4.02 & 9497.0 & 0.002 & 4.02 & 4.21 & 12360.0 & 0.047 \\
\hline & $(0.67)$ & $(0.74)$ & & & $(0.77)$ & $(0.65)$ & & \\
\hline \multirow{2}{*}{ Simple Living } & 4.18 & 3.91 & 9331.0 & 0.001 & 3.93 & 4.09 & 12579.0 & 0.080 \\
\hline & $(0.64)$ & $(0.68)$ & & & $(0.72)$ & $(0.58)$ & & \\
\hline
\end{tabular}

Note: the difference is significant when $\mathrm{p} \leq 0.05$

The other norm of conduct, which is simple living, showed statistically significant differences when employees were grouped according to age ( $p-0.007)$ and employment status $(p=0.001)$; hence, the hypothesis is rejected because $p$ values were less than 0.05 . When employees were grouped according to sex $(p=0.123)$; length of service $(p=0.080)$ where $p$ values are higher than 0.05 hence not significant, the null hypothesis is accepted. These no significant differences in simple living are true on both sexes and for those who had been in service for longer and shorter periods because employees experienced a lack of finances to maintain a dignified life. This finding was also revealed in the studies of Andrew (2017), Narimani et al. (2012), Mitonga-Monga and Flotman (2017), Piosik et al. (2019), Antonaras et al. (2018), and Safdarian et al. (2017), whom all concluded that employees do not practice simple living. On the other hand, the study of Mangaoang (2020) revealed that some provisions in government policies might have enabled the indiscriminate hiring of contractual and job order workers that created alienation of local government employees. This practice leads to employees taking advantage of the time they are connected with the government.

\section{Difference in the level of Job Performance of government employees}

Tables $4 \mathrm{~A}$ and $4 \mathrm{~B}$ present the difference in the level of the job performance of government employees. According to the Mann Whitney $U$ Test performed among employees, the job averages of younger employees were higher than that of the older employees, averages for females were also higher than males; averages for regular employees were higher than non-regular, and those longer in the services showed higher means than employees shorter in the service. Hence it had been observed that the level of the job performance of employees in terms of quality, efficiency, and timeliness as a whole is significant. Thus, the null hypothesis is rejected. In the light of all these results, the effect of demographic characteristics of the respondents on their level of performance is observed. However, it is frustrating that government employees do not observe the same level of performance when their demographics are considered. 
Table 4A. Difference in the level of the job performance of local government employees

\begin{tabular}{lcccccccc}
\hline \multirow{2}{*}{ Variable } & \multicolumn{4}{c}{ Age } & \multicolumn{5}{c}{ Sex } \\
\cline { 2 - 9 } & Young & Old & $\mathbf{U}$ & $\mathbf{p}$ & Male & Female & $\mathbf{U}$ & $\mathbf{p}$ \\
\hline Job & 4.15 & 3.95 & $14101.5^{*}$ & 0.007 & 3.94 & 4.14 & $14304.5^{\star}$ & 0.034 \\
Performance & $(0.73)$ & $(0.70)$ & & & $(0.75)$ & $(0.69)$ & & \\
\hline \multirow{2}{*}{ Quality } & 4.26 & 4.02 & $14267.0^{*}$ & 0.011 & 4.03 & 4.23 & 14694.5 & 0.082 \\
& $(1.06)$ & $(0.74)$ & & & $(0.79)$ & $(1.00)$ & & \\
\hline \multirow{2}{*}{ Efficiency } & 4.17 & 3.98 & $14529.0^{*}$ & 0.023 & 3.93 & 4.18 & $13713.0^{*}$ & 0.007 \\
& $(0.70)$ & $(0.79)$ & & & $(0.83)$ & $(0.67)$ & & \\
\hline \multirow{2}{*}{ Timeliness } & 4.13 & 3.96 & $14766.0^{*}$ & 0.041 & 3.91 & 4.15 & $13827.5^{*}$ & 0.009 \\
& $(0.68)$ & $(0.77)$ & & & $(0.80)$ & $(0.65)$ & & \\
\hline
\end{tabular}

Note: the difference is significant when $\mathrm{p} \leq 0.05$

Table 4B. Difference in the level of the job performance of local government employees

\begin{tabular}{lcccccccc}
\hline \multirow{2}{*}{ Variable } & \multicolumn{4}{c}{ Employment } & \multicolumn{5}{c}{ Length of Service } \\
\cline { 2 - 9 } & Regular & $\begin{array}{c}\text { Non- } \\
\text { regular }\end{array}$ & U & $\mathbf{p}$ & Shorter & Longer & U & p \\
\hline Job & 4.21 & 4.00 & $9716.5^{*}$ & 0.004 & 4.00 & 4.17 & $12308.5^{*}$ & 0.042 \\
Performance & $(0.66)$ & $(0.73)$ & & & $(0.76)$ & $(0.58)$ & & \\
\hline \multirow{2}{*}{ Quality } & 4.32 & 4.09 & $9545.0^{\star}$ & 0.002 & 4.09 & 4.26 & $12377.5^{\star}$ & 0.049 \\
& $(0.66)$ & $(0.98)$ & & & $(1.03)$ & $(0.61)$ & & \\
\hline \multirow{2}{*}{ Efficiency } & 4.23 & 4.03 & $10052 .{ }^{*} 0$ & 0.013 & 4.02 & 4.22 & $12047.0^{\star}$ & 0.020 \\
& $(0.76)$ & $(0.74)$ & & & $(0.77)$ & $(0.70)$ & & \\
\hline \multirow{2}{*}{ Timeliness } & 4.15 & 4.02 & $10604.5^{*}$ & 0.067 & 3.99 & 4.18 & $12278.5^{\star}$ & 0.038 \\
& $(0.77)$ & $(0.71)$ & & & $(0.74)$ & $(0.67)$ & & \\
\hline
\end{tabular}

Note: the difference is significant when $\mathrm{p} \leq 0.05$

This finds support in the study of Usop et al. (2013) that younger employees were rated higher than older employees because work performance declines with increasing age which affects worker performance due to deterioration in abilities, such as speed, adaptability, effectiveness, motor coordination, and strength (Omori \& Bassey, 2019).

Females were rated higher than males because they are more cautious, friendly, and allot time to manage papers and documents for action. Uddin, Rahman, \&Howladar (2017 agreed that males are more contented with mediocre outputs than females. The findings that regular employees were rated higher than non-regular imply that regular employees are efficient and knowledgeable have mastered their jobs and possessed a significantly higher level of initiative. Employees who have served government for a longer period were rated higher than those in service for short periods because they have developed a loyalty to the organization, supporting studies of Andrew (2017) and Usop et al. (2013).

In terms of individual variables, when variable quality was considered, sex revealed no significant difference with a $p$-value of 0.082 . In terms of timeliness, employment status showed no significant difference with a $p$-value of 0.067 . In this case, the hypothesis is accepted. This finding on quality means that both males and females deliver quality service. It is statistically meaningful that the performance of employees in terms of quality is high. While the finding on timeliness means that regardless of whether the employee is holding a regular or non-regular appointment, the delivery of services depends on the schedule of the employees, which was also revealed by the lowest rating on timeliness. 


\section{Relationship between work ethics and job performance}

Table 5 shows a relationship between work ethics and performance of government employees using Spearman Rank Correlation. The study revealed a significant relationship between work ethics and performance which means that a link exists between work ethics influence on work performance. It is statistically meaningful that the work ethics general score level of the respondents affects work performance $(p=0.807, d f=365 ; p=0.000)$. Among the new knowledge is the extraordinary discovery that employees practicing good work ethics contribute beneficial changes to governance revealed on their outstanding job performance but is affected by their demographics. Further, with the government providing an enabling environment, employees can deliver outstanding performance. Another new knowledge developed in this study is that the government being at the helm of enforcement of laws and employers of millions of individuals who lack decent, secure jobs, has to set progressive reforms in public governance focused on the practice of work ethics. This further implies that the awards and recognition received by the LGU, such as the Seal of Good Environmental Governance, contribute to the performance of the employees anchored on their practice of good work ethics.

Findings of a significant relationship between work ethics and job performance validated studies conducted by Rahiman and Kodikal (2017), Usop et al. (2013), Hettiararchchi and Jayarathna (2014), and Inuwa (2016) but did not utilize demographics of respondents. Other studies showing the significant relationship between work ethics and job performance are of Andrew (2017), Safdarian et al. (2017), and of Campbell and Zegwaard (2012) that professional values earned from a code of ethics are directly related to job performance.

Table 5. Relationship between work ethics and job performance

\begin{tabular}{lcll}
\hline Variable & $\mathbf{p}$ & $\mathbf{d f}$ & $\mathbf{p}$ \\
\hline Work Ethics $x$ Job Performance & $0.807^{\star}$ & 365 & 0.000 \\
\hline Note: *the correlation is significant when $\mathrm{p} \leq 0.05$ & &
\end{tabular}

\section{Challenges encountered by government employees.}

Table 6 presents the challenges encountered by government employees in the workplace. The two most significant challenges being identified is "conflict/issues in the workplace", and "employees not aware of the provisions of RA 6713", interpreted as related to a deficiency in management and execution, lack of line managements' commitment, and lack of communication strengthened the findings of Seotlela and Miruka (2014).

Table 6. Challenges encountered by government employees

\begin{tabular}{lcc}
\hline Challenges & f & \% \\
\hline Conflicts in the workplace & 183 & 49.9 \\
Employees' unawareness of RA 6713 & 151 & 41.1 \\
Employees' concern for ethics & 139 & 37.9 \\
Infrequent ethics training & 126 & 34.3 \\
Ethics not discussed & 110 & 30.0 \\
Unequipped employees & 106 & 28.9 \\
Favoritism & 106 & 28.9 \\
No appreciation of deserving employees & 104 & 28.3 \\
Working overtime & 103 & 28.1 \\
Uneven distribution of tasks & 102 & 27.8 \\
Bullying & 99 & 27.0 \\
Office politics & 91 & 24.8 \\
Unhappy employees & 70 & 19.1 \\
\hline
\end{tabular}

The next three challenges concerned with the practice of work ethics: lack of concern for ethics, infrequent conduct of ethics training, and ethics not discussed in the workplace are manifestations of the lack of values and ethical guidelines for administrative and organizational functions (Ravangard et al., 2014). Thus, Terry et al. (2015) proposed that training and capacity building are required to meet the needs of the staff. Other challenges include practices of supervisors such as "favoritism", 
"uneven distribution of tasks", "bullying", and "office politics", which are management implementation deficiencies that Pace (2011) related to poor executive management. The uneven distribution of tasks aligned with the studies of Srikumar et al. (n.d.), Bindra (2017), and Satija and Satija (2012). When the respondents were given the checklist during the conduct of the study, the researcher asked them follow-up questions to ensure that they understood all the written items.

\subsection{Conclusion}

Ethics influences performance revealed by government employees complying with most norms of conduct prescribed by law. However, when economic issues are concerned, ethics are compromised. Hence, it is recommended that the HR program create an ethics advisory board, the conduct of reality check, ethics audit, ethics manual and integrity testing, and performance rewards. Government employees are capable of providing outstanding services when empowered, given the enabling environment.

\section{REFERENCES}

Aktar, S., Sachu, M. K., \& Ali, M. E. (2012). The impact of rewards on employee performance in commercial banks of Bangladesh: an empirical study. IOSR Journal of Business and Management, 6(2), 9-15.

Alegata, W. C. G. \& Caelian, M. V. (2019). The Implementation of the anti-red tape act and client satisfaction of state universities and colleges in Negros Occidental. Philippine Social Science Journal, 2(1), 118-118.

Andrew, A. (2017). Employees' commitment and its impact on organizational performance. Asian Journal of Economics, Business, and Accounting, 1-13.

Antonaras, A., Iacovidou, M., \& Dekoulou, P. (2018). Developing a university CSR framework using a stakeholder approach. World Review of Entrepreneurship, Management, and Sustainable Development, 14(1-2), 43-61.

Aranas, A. G. L. (2016). Bureaucracy on the trail: ethical standards for public officials and employees. Theoretical \& Applied Science, (5), 22-25.

Banks, S. (2012). Ethics and values in social work (4th ed.). Basingstoke: Palgrave Macmillan.

Bashir, M. S., Machali, M. M., \& Mwinyi, A. M. (2012). The effect of service quality and government role on customer satisfaction: Empirical evidence of microfinance in Kenya. International Journal of Business and Social Science, 3(14).

Bibus, A. A. (2013). Applying approaches from moral philosophy, especially virtue ethics, when facing ethical dilemmas in social work. Journal of Czech and Slovak Social Work, 13, 33-50.

Bindra, V. (2017). Effective planning and time management. Bloomsbury Publishing.

Bustamante, C., Salillas, J., Salmingo, R., \& Sy, J. (2017). Solid waste management system deployment in Cadiz City, Negros Occidental. International Association of Engineering and Technology Researchers.

Campbell, M. \& Zegwaard, K. E. (2012, November). Developing an ethical professional through work-integrated learning. In 2012 Australian Collaborative Education Network National Conference (p. 20).

Carmines, E. G., \& Zeller, R. A. (1979). Reliability and validity assessment. Sage publications.

Civil Service Commission. (2019). http://www.csc.gov.ph/2014-02-21-08-28-23/pdf-files/ category/168-ra-6713code-of-conduct-and-ethical-standards.

Dulebohn, J. H., Molloy, J. C., Pichler, S. M., \& Murray, B. (2009). Employee benefits: Literature review and emerging issues. Human Resource Management Review, 19(2), 86-103.

Esser, F. \& Vliegenthart, R. (2017). Comparative research methods. The international encyclopedia of communication research methods, 1-22.

Faragher, E. B., Cass, M., \& Cooper, C. L. (2013). The relationship between job satisfaction and health: a meta-analysis. In From Stress to Wellbeing Volume 1 pp. 254-271). Palgrave Macmillan, London.

Gebre-Egziabher, T. T. (2016). An exploration of work ethics in the Ethiopian civil service: the case of selected federal institutions (Doctoral dissertation). 
.Hameed, A., Ramzan, M., \& Zubair, H. M. K. (2014). Impact of compensation on employee performance (empirical evidence from the banking sector of Pakistan). International Journal of Business and Social Science, 5(2).

Hassan, M., Hassan, S., Khan, M. F. A., \& Iqbal, A. (2013). Impact of HR practices on employee satisfaction and employee loyalty: An empirical study of government-owned public-sector banks of Pakistan. Middle-East Journal of Scientific Research, 16(1), 01-08.

Hettiararchchi, H. A. H. \& Jayarathna, S. M. D. Y. (2014). The effect of employee work-related attitudes on employee job performance: A study of tertiary and vocational education sector in Sri Lanka.

IBON Foundation, (2021). Retrieved from https://www.ibon.org/wage-hike-necessary- overdueamid-pandemic-and-high-prices/

International Monetary Fund. (2019). https://www.imf.org/external/pubs/ft/fandd/2019/09/tacklingcorruption-in-sub-saharan-africa-sobrinho.htm

Inuwa, M. (2016). Job satisfaction and employee performance: An empirical approach. The Millennium University Journal, 1(1), 90-103.

Ismyrlis, V. \& Moschidis, O. (2015). The effects of ISO 9001 certification on the performance of Greek companies. The TQM Journal.

Johnson, R. R. \& Kuby, P. J. (2011). Elementary statistics. Cengage Learning.

Louangrath, P. I., \& Sutanapong, C. (2018). Validity and reliability of survey scales. Int. J. Res. Methodol. Soc. Sci, 4, 99-115.

Mangaoang, E. M. D. (2020). Precarious work in the Philippine public sector: Nuances and prospects for reform.

Mitonga-Monga, J. \& Flotman, A. P. (2017). Gender and work ethics culture as predictors of employees' organizational commitment. Journal of Contemporary Management, 14(1), 270290.

Moralista, R. B., Delariarte, G. C., \& Contreras, R. C. C. (2015). Practices in transparency and effectiveness of government officials and workers. Asia Pacific Journal of Multidisciplinary Research, 3(3).

Narimani, S., Fallah, Z., Narimani, M., \& Hasanpour, M. (2012). The relationship between work ethics and perception of equality among the faculty members and staff of Islamic Azad University of Iran.

Omori, A. E., \& Bassey, P. U. (2019). Demographic characteristics and workers' performance in public service in Nigeria. International Journal of Research and Innovation in Social Science, 3(2), 141-146.

Osibanjo, A. O., Akinbode, J., Falola, H. O., \& Oludayo, O. O. (2018). Work ethics and employees' job performance. Journal of Leadership, Accountability, and Ethics, 2(1), 107-117.

Pace, A. (2011). A new era of performance management. T+ D, Training and Development, 12.

Parvin, M. M. \& Kabir, M. N. (2011). Factors affecting employee job satisfaction in the pharmaceutical sector. Australian Journal of Business and Management Research, 1(9), 113.

Piosik, A., Strojek-Filus, M., Sulik-Górecka, A., \& Szewieczek, A. (2019). Gender and age as determinants of job satisfaction in the accounting profession: Evidence from Poland. Sustainability, 11(11), 3090.

Rahiman, M. H. U. \& Kodikal, R. (2017). Impact of employee work-related attitudes on job performance. British Journal of Economics, Finance and Management Sciences, 13(2), 93-105.

Ravangard, R., Sajjadnia, Z., Jafari, A., Shahsavan, N., Bahmaie, J., \& Bahadori, M. (2014). The association between work ethics and attitudes towards organizational changes among the administrative, financial, and support employees of general teaching hospitals. Journal of Medical Ethics and the History of Medicine, 7.

Reyes, J. C. (2013). Measures of service quality between local government units of Angeles and San Fernando in the Province of Pampanga, Philippines: Its implications to constituents' satisfaction. The International Journal of Social Sciences, 18(1), 13-21.

Ridzuan, A. A., Husin, W. N. W., \& Mujani, W. K. (2017, May). Islamic work ethic elements and soldiers' work performance. In 2017 International Conference on Education, Economics, and Management Research (ICEEMR 2017). Atlantis Press.

Sable, S. (2014). The politics of ethics in public service in the Philippine government: culture of compliance than a continuum. Conference paper, September 2014. 
Safdarian, A., Alavi, A., \& Moaiedfar, H. (2017). An investigation of the relationship between the components of the work ethic and organizational commitment among the staffs of Isfahan University of Medical Sciences. International Journal of Educational and Psychological Researches, 3(1), 61.

Sapada, A. F. A., Modding, H. B., Gani, A., \& Nujum, S. (2018). The effect of organizational culture and work ethics on job satisfaction and employee performance.

Satija, S. \& Satija, P. (2012). Time management: An insight from the Indian perspective. PURUSHARTHA-A Journal of Management, Ethics, and Spirituality, 5(2), 115-134.

Seotlela, R. P. J. \& Miruka, O. (2014). Implementation challenges of performance management system in the South African mining industry. Mediterranean Journal of Social Sciences, 5(7), 177.

Singh, A. K. (2016). Competitive service quality benchmarking in the airline industry using AHP. Benchmarking: An International Journal.

Singh, J. \& Singh, H. (2012). Continuous improvement approach: state-of-art review and future implications. International Journal of Lean Six Sigma.

Srikumar, M. R., Scholar, M., \& Arun, K. Implementation of time management, issues and challenges: An empirical study.

Terry, D., Lê, Q., Nguyen, U., \& Hoang, H. (2015). Workplace health and safety issues among community nurses: a study regarding the impact on providing care to rural consumers. BMJ Open, 5(8).

Uddin, M. A., Rahman, M. S., \& Howladar, M. H. R. (2017). Empirical study on transformational leadership, deviant behaviour, job performance, and gender: Evidence from a study in Bangladesh. European Journal of Management Studies, 22(2), 77-97.

United Nations Development Programme. (2008). http://Report_Tackling_Corruption_Transforming_ Lives.pdf

Usop, A. M., Kadtong, M. L., \& Usop, D. A. S. O. (2013). The significant relationship between work performance and job satisfaction in the Philippines. International Journal of Human Resource Management and Research, 3(2), 9-1

\section{Correspondence:}

HELEN R. BENEDICTO

helenbenedicto0523@gmail.com

https://orcid.org/0000-0003-0438-8949

MERLITA V. CAELIAN

merlita_caelian@yahoo.com

https://orcid.org/0000-0002-4671-4047 